\title{
Project EASTMAR: acquisition of high sensitivity aeromagnetic data off East Greenland
}

\section{H. C. Larsen and L. Thorning}

Project EASTMAR, an aeromagnetic survey of major parts of the continental margin off East Greenland, is an energy research project originally funded by the Danish government through the Energy Agency (Thorning, 1978; Larsen \& Thorning, 1979). During 1979, the EASTMAR project has been included in an EEC supported geophysical project called the NAD project (North Atlantic D; see also Risum, this volume). The aim of the NAD project is to map the deep and regional structures of the continental margin off East Greenland by using high sensitivity aeromagnetic surveys, multichannel seismic reflection and marine gravity surveys, and to prepare a preliminary assessment of the petroleum geology of the region. In 1979, the main work of EASTMAR has been the acquisition of new aeromagnetic data between latitudes $60^{\circ} \mathrm{N}$ and $80^{\circ} \mathrm{N}$ in accordance with the flight programme (fig. 31; and Larsen \& Thorning, 1979) and compilation of existing aeromagnetic and seismic data (Larsen, 1980).

\section{Field operations}

The survey operations were carried out by Aero Service Division, Western Geophysical Company of America. These started from Narssarssuaq air field in South Greenland on 1st April and were completed from Reykjavik Airport, Iceland, on 10th September. The flight programme was fulfilled with only minor changes except for area 5 which was partly omitted at GGU's request. Two additional lines between area $3 \mathrm{M}$ and Reykjavik were collected during ferry flights.

All operations were carried out by one aircraft (DC3, 11 hours range) with one crew. Quality control was exercised continuously by Aqua-Terra Consultants of Calgary, Canada.

The survey aircraft was equipped with a Varian optical pumped Cesium-Vapour magnetometer with a 6-cell sensor carried in a towed bird. Flight altitude was continuously at 2000 feet above sea level (sensor approximately at 1875 feet above sea level) except area 4 and profile I and II (6000 feet above sea level and drape flying).

A fully integrated navigation system comprising two INS platforms (LTN 56), one radardoppler system and two Loran $\mathrm{C}$ receivers (range - range mode) was operated through all flights. In areas with poor Loran $\mathrm{C}$ coverage (mainly from $63^{\circ} \mathrm{N}$ and southwards), the INS platforms were operated $1 \frac{1}{1 / 2}$ hours after landing for later corrections of Schuler-drift. All coastal ties were recorded on film for possible updating during compilation.

Narssarssuaq was the operational base until the middle of May followed by Kulusuk until late June, Mesters Vig from early July to late August, and Reykjavik until completion.

Approximately 63000 line $\mathrm{km}$ of acceptable data were collected. Weather conditions were the most serious obstacle to the survey operations. Loss of time due to instrument failure or aircraft on ground was negligible. Reflights, mainly due to diurnals, constitute about 15 percent of the total flown mileage (excluding ferry flights). As a rough average, operations were possible one out of three days, and consequently production was about 1000 line $\mathrm{km}$ per operational day. 


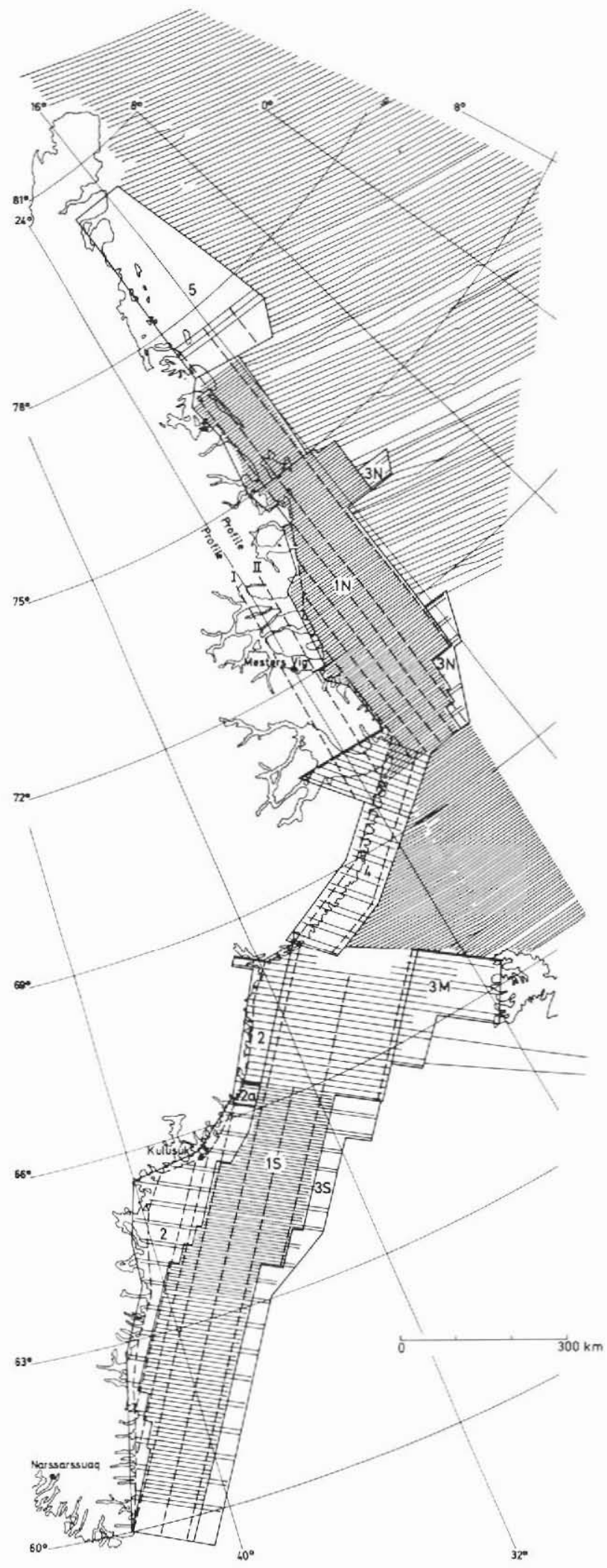

Fig. 31. Map showing flight programme carried out during 1979 and U.S. Navy data compiled within GGU (outside numbered blocks, see Larsen \& Thorning, 1979 for references). Note that coverage of area 5 has been reduced and that two additional lines (ferry flights, positions only sketched) have been made between area $3 \mathrm{M}$ and Iceland when compared to the preliminary flight line map (Larsen \& Thorning, 1979). The data collected by Larsen (1974) and the data presented here now supply a complete coverage of all major off- and onshore post-Caledonian sedimentary basins between latitudes $60^{\circ} \mathrm{N}$ and $77^{\circ} \mathrm{N}$. The geological background to the flight programme has been reviewed in Larsen \& Thorning (1979). 


\section{Data quality}

Quality evaluation of the total body of data must await compilation and interpretation. However, all profiles were quality controlled in the field by Aqua Terra. Data collected during periods of excessive diurnal activity (in most areas defined as non-linear variations exceeding five gammas in five minutes) or data collected from an excessive flight altitude were voided and reflights were performed. Interpretation of anomalies down to one gamma size was performed on analogue records during field operations and digital data are expected to be reliable down to a few tenths of a gamma (relative anomalies). Positional accuracy is usually better than a few hundred metres in areas with good Loran C coverage (most of the survey area), and outside this positional errors should not exceed about $500 \mathrm{~m}$ after compilation.

Line to line correlation of anomalies was fair to good throughout the flight programme. The western landward boundary of the offshore sedimentary basins was continuously covered by the dense grid, and oceanic basement was encountered on all seaward extended lines. Altogether, the high sensitivity aeromagnetic data collected during 1979 seem to be of very good quality.

Project EASTMAR incorporates the use of aeromagnetic data previously collected by various U.S. Navy agencies (Larsen \& Thorning, 1979; and fig. 31). Compilation and interpretation of this data has progressed during 1979 and revealed mixed and somewhat poor data quality when compared to the new data. Local positional inconsistencies, irregular sample spacing, spikes and occasional noise with amplitude in the order of several gammas occur throughout the data. Nevertheless, the U.S. Navy data are very informative with regard to regional structures (Larsen, 1980) and preparation of rough depth-to-basement maps are still considered possible.

\section{Compilation - interpretation schedule}

Both the acquisition and the compilation of the new data have been contracted to Aero Service. GGU will compile the U.S. Navy data and carry out the interpretation of all data. Completion of compilation is expected about March 1980 and availability of a first interpretation is expected early in 1981 .

\section{Acknowledgements}

Thanks are due to the Aero Service crew for its continuous efforts to fulfil the flight programme and to Aqua Terra for its careful quality control.

In particular, we acknowledge the competent management of field operations by project manager Frank Ragan and the careful execution of the flight plan by chief pilot Everett Seath. 


\title{
References
}

Larsen, H. C. 1975: Aeromagnetic investigations in East Greenland. Rapp. Grønlands geol. Unders. 75, $88-91$.

Larsen, H. C. 1980: Geological perspectives of the East Greenland continental margin. Bull. geol. Soc. Denmark, 29.

Larsen, H. C. \& Thorning, L. 1979: Project EASTMAR: planning of an aeromagnetic survey off East Greenland. Rapp. Gronlands geol. Unders. 95, 93-96.

Thorning, L. 1978: Project EAstMar: a new aeromagnetic survey of the continental shelf of eastern Greenland. Rapp. Grønlands geol. Unders. 90, 113-115.

\section{A marine geophysical survey of the East Greenland continental shelf between latitudes $60^{\circ}$ and $70^{\circ} \mathrm{N}$ - Project DANA 79}

\author{
Birger Larsen
}

\section{Introduction}

Project DANA 79 is a part of GGU's geophysical investigations of the East Greenland shelf with special reference to the oil and gas potential of the continental margin. The programme also includes a regional aeromagnetic survey called EASTMAR (Larsen \& Thorning, this report) and the planned deep seismic investigations (Risum, this report). Project DANA 79 was designed to provide knowledge of the geology of the sea floor and the shallow $(0-300 \mathrm{~m})$ subsurface. Special emphasis was put on the delineation of the basement and of the sedimentary basins on the shelf. The project was mainly sponsored as an energy related research programme by the Danish Ministry of Trade, Industry and Shipping, and was also supported by the Danish Natural Science Research Council.

\section{The survey}

The survey was carried out by a GGU team of ten, assisted by the crew of nine onboard the M/V Dana. Approximately 10000 line kilometres of shallow seismic, magnetic and bathymetric profiles were measured together with 1000 line kilometres of side scan data. The lines shown in fig. 32 were measured from 27 th July to 2 nd September during unusually good weather and ice conditions. In addition approximately 2000 line kilometres were measured from 6th July to 27th July around the Faeroe Islands for the Geological Survey of Denmark and the government of the Faeroes (Nielsen et al., 1979). The lines were investigated through a single channel, analogue recorded, continuous shallow seismic system. The energy source was either a 10 or 20 cubic inch airgun or a $4 \mathrm{KJ}$ sparker. A deep tow 